\title{
Gender Variation in the Emotional Construal of Russian Journalistic Non-fiction
}

\begin{abstract}
Aвstract: Šipka Danko, Gender Variation in the Emotional Construal of Russian Journalistic Non-fiction, "Poznańskie Studia Slawistyczne" 9. Poznań 2015. Publishing House of the Poznań Society for the Advancement of the Arts and Sciences, pp. 149-167. ISSN 2084-3011.

The author analyzes gender differences in the Russian journalistic discourse using the example of the lexical field related to the concept of zрусть 'sorrow'. The more frequent use of these words is indicative of a higher level of empathy. The results demonstrate that male authors exhibit a higher proclivity towards the usage of the words from the aforementioned lexical field. The results are another piece of evidence that a higher level of empathy in women is not absolute but rather highly dependent on the concrete context.
\end{abstract}

KEYwORDS: gender differences; Russian; journalistic discourse; empathy; lexical usage

\section{Introduction}

The present multidisciplinary research ties into three areas of cognitive sciences. First, it is related to the psychological study of gender and empathy. Second, it draws upon the tradition of (Slavic) gender linguistics. Finally, the present research is related to the linguistic study of emotion.

There is a common theme in social psychology about gender differences in various aspects of emotional processing. Although there exists a general popular perception about a higher level of empathy in women, scholarly literature on that subject paints a more complex picture. As demonstrated in a recent study on the subject (Rueckert 2011: 221), crossgender differences in empathy are dependent on the concrete context:

There is a long-standing belief amongst both psychologists and lay people that women are more emphatic than men. In reality, the scientific literature is mixed. While women consistently self-report higher levels of empathy, studies utilizing other, more 
objective measures, have reported little or no gender difference. (...) It appears that the female advantage in empathy is not absolute, but depends on the type of empathy measured and various contextual factors, such as the instructions given or the relationship between the empathizer and the person with whom they are empathizing.

In the present research, the question is how the context of journalism affects gender differences in empathy. This particular context gives us the opportunity to see how contextual factors influence the discourse about empathy in pre-existing data, i.e., in a non-experimental context.

The second relevant research tradition, maintained by gender linguistics in general (see for example: Hellinger, Bußmann 2003, Cameron 1992, Eckert, McConnell 2003, Mills S. 2003, 2012) and Slavic gender linguistics in particular (e.g.: Mills M.H. 1999), has devoted considerable attention to various gender linguistic issues: virility, gender roles and perception, gender and diminutivization etc. The general idea of gender inequality in Slavic languages and cultures, which is well documented in this tradition, would point to the possibility that these differences may reveal themselves in the use of empathy-related vocabulary in a journalistic discourse. Given traditional gender roles, one would expect a higher use of such vocabulary items in females.

One should finally mention the linguistic study of emotion. Linguistic aspects of emotion have been addressed in a broad array of papers and monographs, from general studies such as Wilce 2009) to those works which concentrate on the conceptualization and expression of emotions (e.g.: Athanasiadou, Tabakowska 1998), to the studies of emotional metaphors (such as Kövecses 2000), to cross-linguistic comparisons, (e.g. Ogarkova, Soriano, Lehr 2012).

The present paper builds upon the three aforementioned traditions in attempting to answer the question if male and female journalistic discourse exhibit differences in the use of the words related to the feelings which can invoke empathy. The goal of this research is thus to place gender differences in a concrete discourse, using a concrete empathy-relevant lexical field. 


\section{Procedure}

The present research looked into the group of Russian words related to the concept of zрyсть 'sorrow' in two journalistic textual subcorpora, one written by female authors and the other written by male authors. The principal research question was if the two corpora exhibit differences in the number of texts in which these words are used. A more frequent use of the aforementioned words could indicate a higher level of empathy, i.e., the ability to recognize sorrow and report about it. The analyses of the Russian emotional concepts from the same semantic field point to the fact that their use is related to a higher level of empathy. One should mention in particular Wierzbicka (1999), who analyzes грусть among other concepts, and Ogarkova, Fontaine, and Prihod'ko (2013), who analyze a similar concept of тоска (defined by Nabokov as follows: „At its deepest and most painful, it is a sensation of great spiritual anguish, often without any specific cause. At less morbid levels it is a dull ache of the soul, a longing with nothing to long for, a sick pining, a vague restlessness, mental throes, yearning. In particular cases it may be the desire for somebody of something specific, nostalgia, love-sickness. At the lowest level it grades into ennui, boredom" - Puškin 1990: 141, note to stanza XXXIV line 8). In addition to the indication about the relation of the conceptual field of грусть 'sorrow' to empathy, there is a common-sense one. It is namely so that the texts analyzed here are general newspaper articles, which means that the author is typically referring to other people when using the words from the lexical field of zрусть 'sorrow'. The mere mentioning of these words is a clear indicator of the author's awareness of that kind of emotion in other people, which in turn also means a higher level of empathy when compared with the authors of the texts where these words are not used.

Russian national corpus (<www.ruscorpora.ru $>$ ) was used to create the two subcorpora. The two subcorpora had one restriction in common (journalistic non-fiction texts) while the gender of the author (female vs. male) was used as the defining restriction for each subcorpus. Subcorpora parameter setting is illustrated in Appendix 3. Quantitative features of the two subcorpora look as follows: 
Corpus total: 85996 documents, 19362746 sentences, 229968798 words.

Female Journalistic Corpus: 8390 documents consisting of 1070582 sentences, 13418493 words.

Male Journalistic Corpus: 20122 documents consisting of 4318938 sentences, 60275922 words.

The list of the words related to the concept of zрyсmь 'sorrow' is based on Бабенко (1989). The original list is presented in Appendix 1 with a slightly modified list, which is used in this particular research, is given in Appendix 2 with the Russian category names translated into English. The only modification was the exclusion of the words which are preponderantly more frequent in their other usage than in the metaphorical usage in this semantic field. For example the word черно 'black' is used for the color much more frequently than for feelings. This particular exclusion was meant to reduce the external variable of additional meanings of some words.

Two frequency counts were performed on the aforementioned female and male corpus. Given that the two corpora were different in their size, the results were normalized by calculating the percentage of the forms in each corpus. First, the frequency count for all lexical items in 18 different categories established by Бабенко (1989) was tabulated, their percentage in the corpus was calculated, which was followed by the computation of the differences between the two corpora. The small number of categories did not allow the use of inferential statistics. Second, the frequency for each unique word, the percentage in the corpus, and the difference between the two corpora were tabulated. Given that the list contained 149 items, it was also possible to compute the T-Test to see if the relationship was statistically significant. The difference between the textual frequencies is expressed as follows: difference $=$ female subcorpus frequency - male subcorpus frequency given the general expectation of a higher use of these words in females.

The present research has three principal limitations. First, there are words in the lexical pool analyzed here that have other meanings that are not related to the lexical field of the word zрyсть. The most drastic examples of such words were excluded from the pool (as mentioned earlier 
in this text), but the effect of the meanings outside of the observed lexical field is still present. One should say, however, that the effect is equally present in both established corpora - female and male. Second, although the effect size was controlled by measuring the percentage of the relevant words and fields in the entirety of the subcorpus, the fact that the male subcorpus was considerably larger still has some effect. Obviously, one should also note that this disproportion in the size simply reflects the differences that objectively exist in the society - a higher number of journalistic texts is penned by males than by females. Given that the goal of this research is to investigate emotional construal in a type of discourse, it had to go with the parameters of that particular discourse. Third and final, this research is determined by all limitations of the Russian National Corpus and Бабенко (1989) which were used to tabulate the frequencies of the relevant words. Again, the female and the male corpus alike were affected by the limitations of the two principal data sources.

\section{Results}

The results of the analysis of the cumulative frequency of the words in the aforementioned 18 lexical fields are presented in Table 1 further in this text. As might be seen, the use of this vocabulary is consistently higher in males. The differences range from $.31 \%$ to $6.19 \%$. On average, males use the words related to the semantic field of грусть $2.52 \%$ more in their particular discourse than females. Given a low number of categories established by Бабенко (1989), it was impossible to check if this relationship would be statistically significant.

The results of the analysis of particular words is provided in Appendix 5. Here too, as was in the case with the categories, males use these words considerably more frequently than their female counterparts. However, in this case that is not universally true. On average, the investigated words have $31 \%$ higher frequency in the male than in the female corpus. Out of 149 words, 125 are used more frequently by males (the difference ranges between $.003 \%$ and $3.76 \%$ ), 15 words have identical frequency in the two corpora, and only nine words are more frequent in the female corpus (ranging from $.004 \%$ to $.5 \%$ ). It is interesting to note that the word where the 


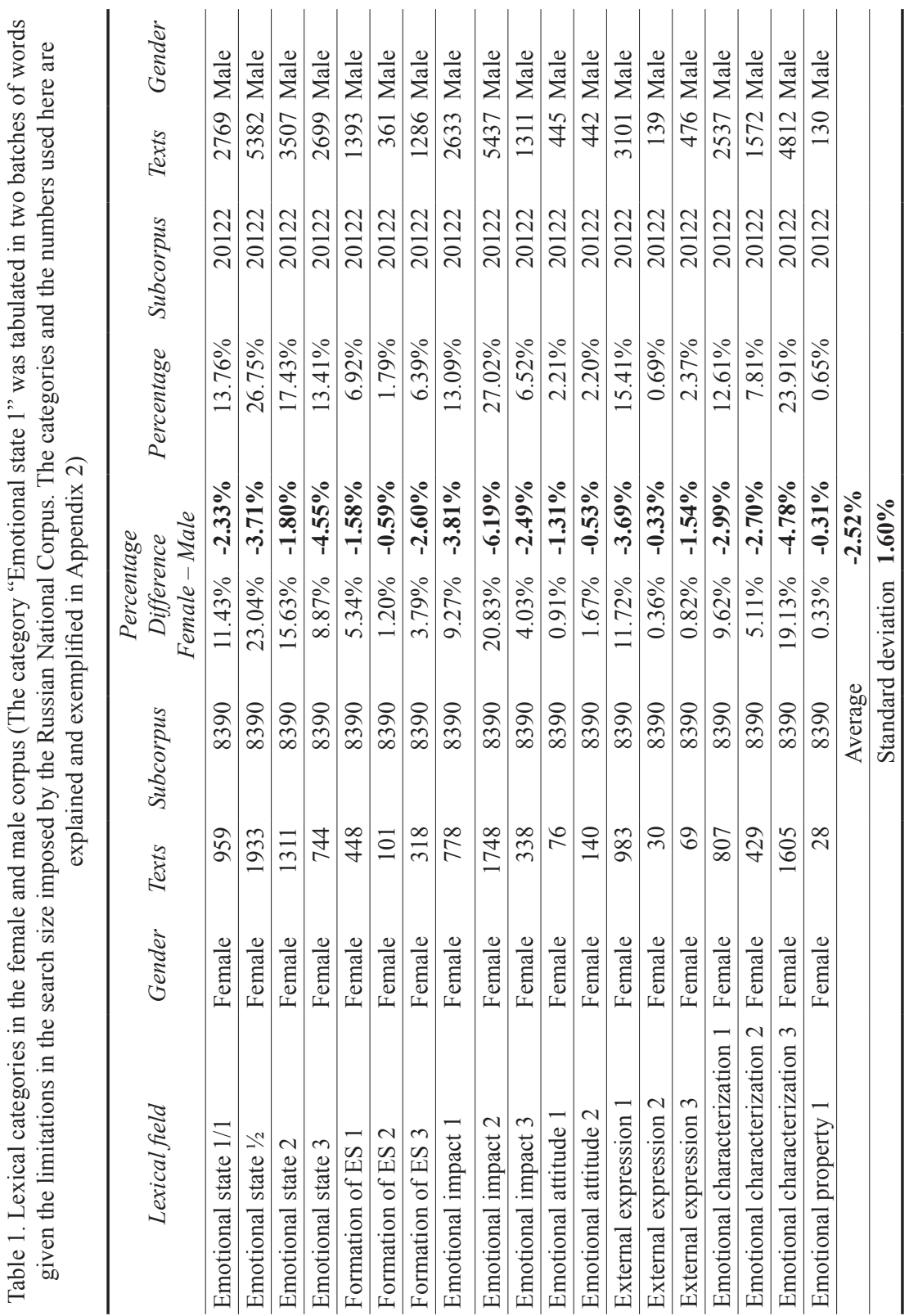


female use is most predominant is депрессия 'depression' (.5\%), with the next most frequent items being considerably lower in the difference $(.126$, $.188, .033$, etc.).

The T-Test results are not straightforward. While the T-Test itself shows that the relationship is not significant (even though it is rather close to the significant range), Levene's test yields statistically significant results, which means that the differences in variance between the two subcorpora are not random. The results are presented in Table 2.

\section{Conclusion}

The present research has brought us to the following conclusions. First, Russian female journalists definitely do not show any proclivity toward a higher use of the vocabulary from the lexical field of грусть. This finding goes along the lines of psychological findings about empathy quoted at the beginning of this paper - females are not generally more empathic than males: their level of empathy is dependent on the concrete context. The data about the use of the lexical field of zрусть are just a limited piece of contributing evidence in favor the aforementioned psychological findings - with them we are, quite obviously, not making a direct claim about empathy per se.

Second, Russian male journalists consistently use the words from the lexical field of zpycms considerably more frequently than females. This goes against the traditional popular construal of gender roles in Slavic languages and societies. Here again, the results are just a small piece of contributing evidence pointing to the fact that linguistic gender differences in one Slavic language and in one particular sphere of usage are much more complex than it is commonly believed.

Third, while we can clearly see the dominance of the observed vocabulary in the male subcorpus, we cannot say that gender is a predictor of vocabulary use (the T-Test turned out not to be statistically significant). What can be stated is that the gender differences in vocabulary use are not random. 


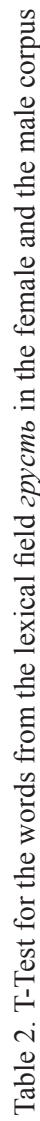

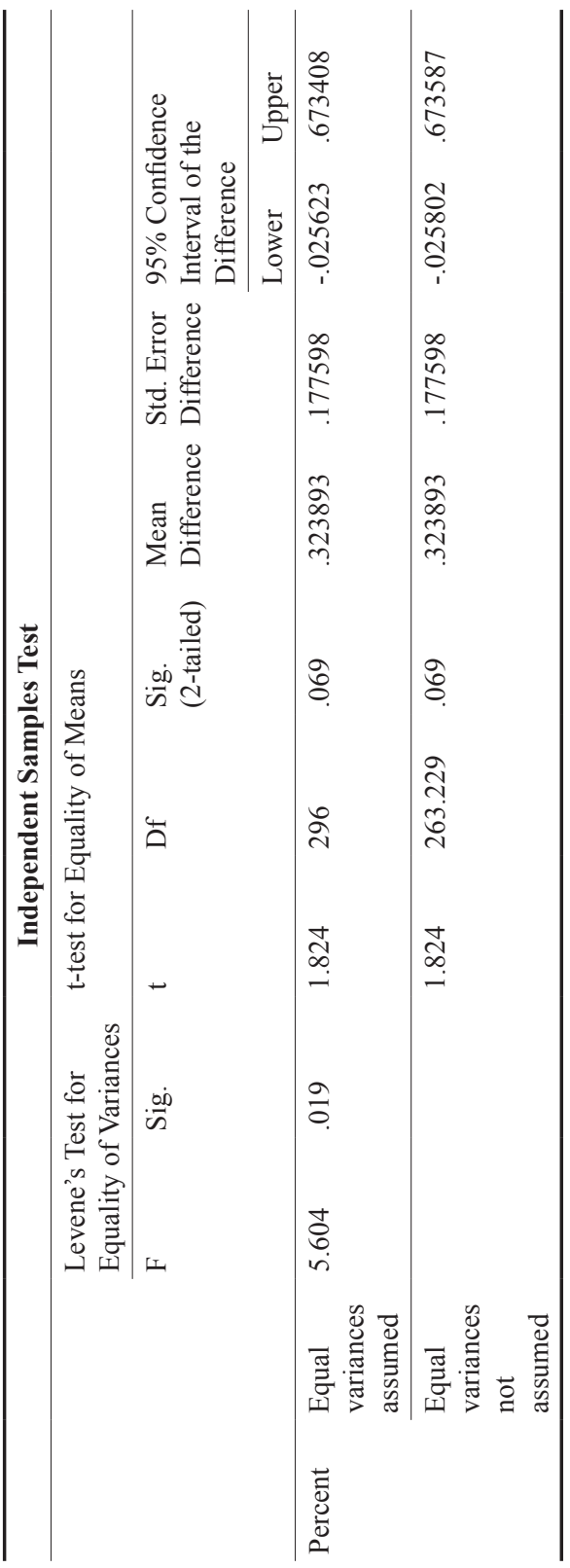




\section{Literature}

Athanasiadou A., Tabakowska E. (eds.), 1998, Speaking of emotions: conceptualization and expression, Berlin.

Cameron D., 1992, Feminism and linguistic theory, Hampshire-New York.

Eckert P., McConnell-Ginet S., 2003, Language and Gender, Cambridge.

Hellinger M., Bußmann H. (eds.), 2003, Gender Across Languages: The Linguistic Representation of Women and Men, vol. 3, Amsterdam.

Kövecses Z., 2000, Metaphor and emotion: language, culture, and body in human feeling, Cambridge.

Mills M.H. (ed.), 1999, Slavic Gender Linguistics, Amsterdam.

Mills S., 2003, Gender and Politeness, Cambridge.

Mills S., 2012, Gender Matters: Feminist Linguistic Analysis, Sheffield.

Ogarkova A., Fontaine J.R.J., Prihod'ko I., 2013, What the GRID can reveal about culture-specific emotion concepts: A case study of Russian 'toska', in: Components of emotional meaning: a sourcebook, eds. J.R.J. Fontaine, K.R. Scherer, C. Soriano, Oxford, p. 353-365, DOI: 10.1093/acprof:oso/9780199592746.001.0001.

Ogarkova A., Soriano C., Lehr C., 2012, Naming feeling. Exploring the equivalence of emotion terms in five European languages, in: Dynamicity in Emotion Concepts, ed. P.A. Wilson, vol. 27, p. 253-284.

Puškin A.S., 1990, Eugene Onegin, trans. V. Nabokov, Princeton.

Rueckert L., 2011, Gender Differences in Empathy, in: Psychology of Empathy, ed. D.J. Scapaletti, Hauppauge, p. 221-234.

Wierzbicka A., 1999, Emotions across Languages and Cultures. Diversity and Universals, Cambridge.

Wilce J.M., 2009, Language and emotion, Cambridge.

Бабенко Л.Г., 1989, Лексические средства обозначения эмоџий в русском языке, Свердловск.

\section{Internet sources}

$<$ www.ruscorpora.ru $>$ 


\section{Appendices}

\section{Appendix 1}

Грусть 'sorrow' in Бабенко (1989: 151-152)

III. Зудеть'́, иридавнть / придавливать2, прицепиться / прнцегляться 2 , прншнбить2, раздавнть / раздавливать, растравнть / растравливать, растравлять, теснить, щемить 1 .

\section{Эмоциональное отномение}

1. Сожалеть.

I1. Вздыхатьр, сожалетьр.

\section{Вмешкее вырахение эмоций}

1. Нерадостный, отчаянный, печальный, понуриться, скучливый,, скучный, томный, тоскливый, уннлый, хмурый.

11. Нюнн 2 , поехатьз, раздосадованный, скучающий

III. Нахохлиться / нахохливаться, хохлиться 2 , теснить / стеснить5, туман ${ }_{2}^{\frac{1}{2}}$.

\section{Эмочиомаяьная характеризачия}

1. Безнадежный, безотрадный,безрадостный, занудный, зуда, кисляй, кручинный, меланхолик, меланхолический, меланхоличка, муторный, мымра, назойливый, опечаленный, отчаянный, пессимист, пессимистка, печальник, печальница, понурый, скучлнвый, скучный, смурной, сушь, хмурый, элегичный.

II. Гнетущий 2 , задавленный, кислятина 2 , мертвящий, монотонны ${ }_{2}$, назола ${ }_{2}$, переутомленный, тоска ${ }_{3}$, туманный, , элегичный 2 .

III. Глушитель ${ }_{3}$, гнет, панихидный 2 , постный, сумеречный, темный 3 , тягучнй

\section{Эмоциональкое качество}

1. Меланхоличность, мрачность, надоедливость, назойливость, пессимистичность, смурость, сокрушнтельность, элегнчность. 


\section{Appendix 2}

Грусть as used in this paper modified Бабенко (1989: 151-152) with categories translated in English

Эмоциональное состояние (emotional state)

1. безнадежность, безотрадность, безысходность, грустить, грустный, грусть, депрессия, журиться, задавленность, затосковать, ипохондрия, кручина, кручиниться, кручинушка, крутиться, кукситься, меланхолия, назола, наскучаться, натосковаться, невеселый, нерадостный, ностальгия, отчаяние, пессимизм, пессимистический, печалиться, опечалиться, печаловаться, печаль, печальный, подавленность, подосадовать, покручиниться, понурость, поскучать, потомиться, потосковать, потужить, сгрустнуться, сетовать, посетовать, скука, скучать, скучища, скучный, сожаление, сокрушаться, соскучиться, сплин, томный, тоска, тоскливость, тоскливый, тосковать, унылость, унылый, уныние, утепление, хандра, хандрить, хмуро, хмурь

2. грустно, невесело, нерадостно, неуютно, нехорошо, нудиться, нудно, омраченный, пакостно, паршиво, печально, погано, подавленный, пришибленный, прозябает, прозябание, раздосадованный, скверно, скучать, скучно, страдать, сумрачно, сумрачный, томиться, тоска, тоскливо, уныло

3. киснуть, минор, минорный, мрак, мрачный, оскомина, пасмурно, темно, тянуть, потянуть, элегия

Становление эмоционального состояния (formation of emotional state)

1. взгрустнуть, взгрустнуться, зажмуриться, закручиниться, крушить, мрачнеть, помрачнеть, надоесть, надоедать, опечалиться, опостынуть, опостыть, отчаяться, отчаиваться, погрустить, помрачиться, помрачаться, понуриться, приуныть, приунывать, раздосадоваться, раскваситься, расквашиваться, растосковаться, растужиться, скукситься скучнеть, поскучнеть, стосковаться, унывать, угоняться, угоняться, хмуриться, нахмуриться

2. взвыть, мрачиться, омрачиться, омрачиться, омрачаться, сокрушенный, соскучиться

3. гнести, давить, затуманиться, затуманиваться, отуманиться, отуманиваться, туманиться, поникнуть, поникать, никнуть, приесться, приедаться, раскиснуть, раскисать, скиснуть, скисать, сникнуть, сникать, темнеть, потемнеть

Эмоциональное воздействие (emotional impact)

1. грустный, заунывный, мрачный, надоедливый, надсадный, наскучить, невеселый, неотвязный, неотвязчивый, несносный, нудный, опечалить, опечаливать, печалить, осточертеть, потомить, прискучивать, протомить, раздосадовать, скучный, унывный, утомительный, утомить, утомлять

2. лезть, неловкий, нудный, омрачить, омрачать. мрачить, печальный, подавить, подавлять, подавляющий, пристать, приставать, сокрушать, сокрушить, сокрушительный, стеснить, утеснять, страшный, сумрачный, томить, тоскливый, унылый 
3. зудеть, придавить, придавливать, прицепиться, прицепляться, пришибить, раздавить, раздавливать, растравить, растравливать, растравлять, теснить, щемить, сожалеть, вздыхать, сожалеть

Эмоциональное отношение (emotional attitude)

1. сожалеть

2. вздыхать

Внешнее выражение эмоций (external expression of emotion)

1. нерадостный, отчаянный, печальный, понуриться, скучливый, скучный, томный, тоскливый, унылый, хмурый

2. нюни, раздосадованный, скучающий

3. нахохлиться, нахохливаться, хохлиться, теснить, стеснить

Эмоциональная характеризация (emotional characterization)

1. безнадежный, безотрадный, безрадостный, занудный, зуда, кислый, кручинный, меланхолик, меланхолический, меланхоличка, муторный, мымра, назойливый, опечаленный, отчаянный, пессимист, пессимистка, печальник, печальница, понурый, скучливый, скучный, смурой, сушь, хмурый, элегичный

2. гнетущий, задавленный, кислятина, мертвящий, монотонный, назола, переутомленный, придавленный, прилипать, смурый, сумрачный, тоска, туманный, элегичный

3. глушитель, гнет, панихидный, постный, прилипчивый, свинцовый, согбенный, сумеречный, темный, тягучий, черный, щемящий.

Эмоциональное качество (emotional property)

меланхоличность, мрачность, надоедливость, назойливость, пессимистичность, смурость, сокрушительность, элегичность

тип значения 1 - основное 2 - номинативно-производное 3 -метафорическипроизводное (the type of meaning 1 - basic 2 referential derivative 3 metaphorical derivative) 


\section{Appendix 3}

Corpus search parameter setting (journalistic texts written by females) from Национальный корпус русского языка (www.ruscorpora.ru)

Subcorpus

$\square$ Disambiguated corpus only ${ }^{?}$

Main parameters ?

Title

Author

Gender: $\bigcirc$ any $O$ male $\bigcirc$ female

Date of birth: between and

Date of creation: between

and

Genre and type ?

1. Fiction $\square$

Genre select

Type select

Type select

Time and place select

2. Non-fiction $\square$

Domain select

публицистика

Type select

Theme select 


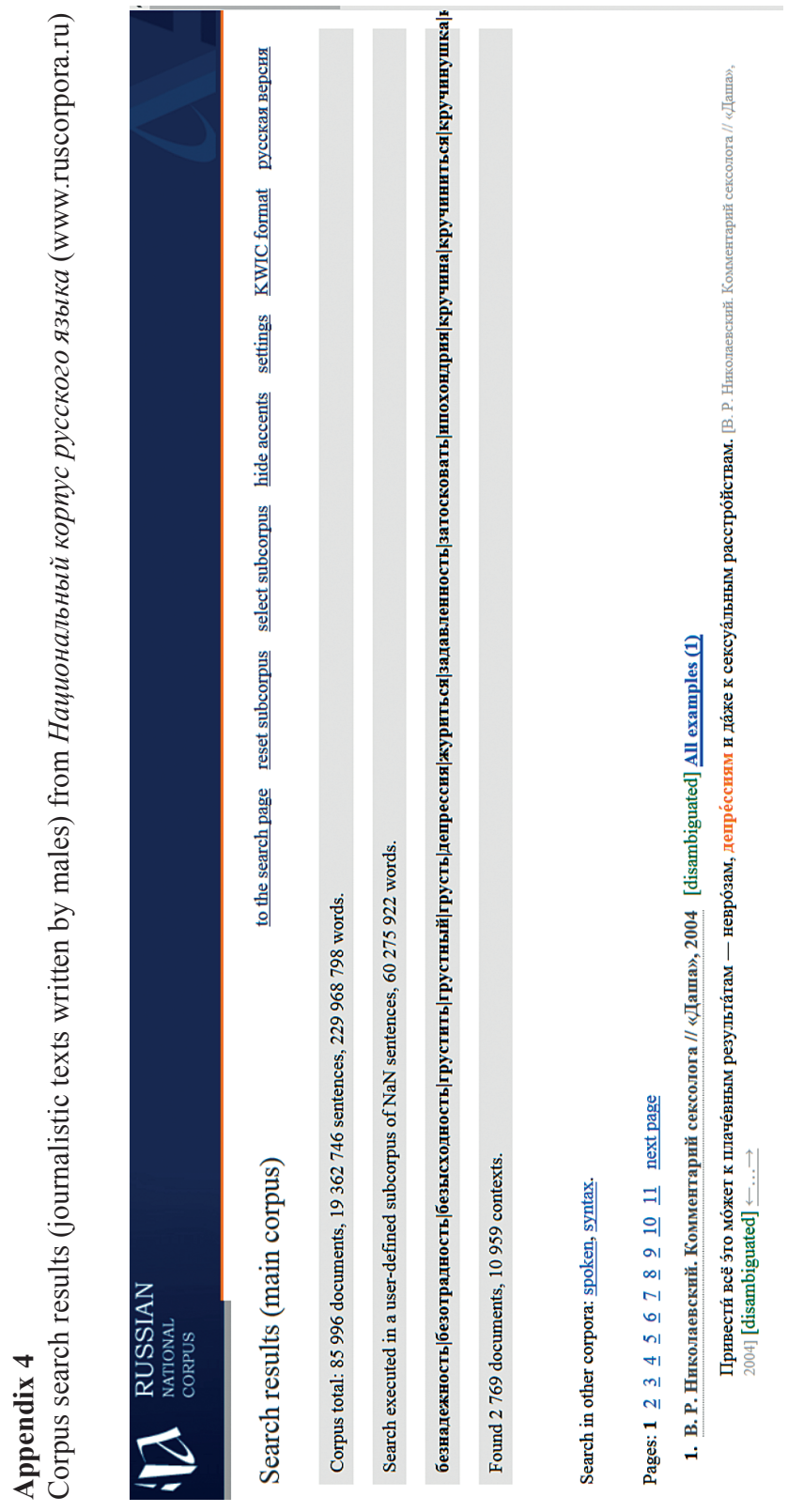




\section{Appendix 5}

Lexical items from the semantic field грусть in the female and male corpus

The first column contains the words used in this count, the second the count in the female corpus, the third the size of the female subcorpus, the fourth percentage in the female corpus, the fifth the difference between the female and male corpus percentage (a positive number means that females use the word more than males, a negative number that males are using the word more frequently than females), the sixth column contains the percentage in the male subcorpus, the seventh the size of the male subcorpus, and the eight the count in the male corpus.

\begin{tabular}{|c|c|c|c|c|c|c|c|}
\hline$\frac{2}{2}$ & 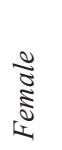 & 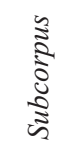 & & 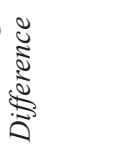 & 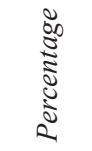 & 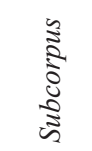 & $\frac{\vec{z}}{z}$ \\
\hline безнадежность & 45 & 8390 & $0.54 \%$ & $-0.507 \%$ & $1.04 \%$ & 20122 & 210 \\
\hline безнадежный & 231 & 8390 & $2.75 \%$ & $-1.923 \%$ & $4.68 \%$ & 20122 & 941 \\
\hline безотрадность & 1 & 8390 & $0.01 \%$ & $-0.048 \%$ & $0.06 \%$ & 20122 & 12 \\
\hline безрадостный & 10 & 8390 & $0.12 \%$ & $-0.582 \%$ & $0.70 \%$ & 20122 & 141 \\
\hline безысходность & 41 & 8390 & $0.49 \%$ & $-0.187 \%$ & $0.68 \%$ & 20122 & 136 \\
\hline взгрустнуть & 5 & 8390 & $0.06 \%$ & $0.005 \%$ & $0.05 \%$ & 20122 & 11 \\
\hline взгрустнуться & 4 & 8390 & $0.05 \%$ & $-0.022 \%$ & $0.07 \%$ & 20122 & 14 \\
\hline грустить & 98 & 8390 & $1.17 \%$ & $-0.412 \%$ & $1.58 \%$ & 20122 & 318 \\
\hline грустный & 362 & 8390 & $4.31 \%$ & $-1.540 \%$ & $5.85 \%$ & 20122 & 1178 \\
\hline грусть & 156 & 8390 & $1.86 \%$ & $-1.103 \%$ & $2.96 \%$ & 20122 & 596 \\
\hline депрессия & 134 & 8390 & $1.60 \%$ & $0.509 \%$ & $1.09 \%$ & 20122 & 219 \\
\hline журиться & 1 & 8390 & $0.01 \%$ & $-0.003 \%$ & $0.01 \%$ & 20122 & 3 \\
\hline задавленность & 1 & 8390 & $0.01 \%$ & $-0.013 \%$ & $0.02 \%$ & 20122 & 5 \\
\hline зажмуриться & 19 & 8390 & $0.23 \%$ & $-0.121 \%$ & $0.35 \%$ & 20122 & 70 \\
\hline закручиниться & 0 & 8390 & $0.00 \%$ & $-0.055 \%$ & $0.05 \%$ & 20122 & 11 \\
\hline занудный & 13 & 8390 & $0.15 \%$ & $-0.074 \%$ & $0.23 \%$ & 20122 & 46 \\
\hline затосковать & 22 & 8390 & $0.26 \%$ & $-0.041 \%$ & $0.30 \%$ & 20122 & 61 \\
\hline заунывный & 26 & 8390 & $0.31 \%$ & $-0.152 \%$ & $0.46 \%$ & 20122 & 93 \\
\hline зуда & 29 & 8390 & $0.35 \%$ & $-0.141 \%$ & $0.49 \%$ & 20122 & 98 \\
\hline ипохондрия & 6 & 8390 & $0.07 \%$ & $-0.097 \%$ & $0.17 \%$ & 20122 & 34 \\
\hline
\end{tabular}


Danko Šipka

\begin{tabular}{|c|c|c|c|c|c|c|c|}
\hline кислый & 111 & 8390 & $1.32 \%$ & $-0.302 \%$ & $1.63 \%$ & 20122 & 327 \\
\hline крутиться & 117 & 8390 & $1.39 \%$ & $-0.424 \%$ & $1.82 \%$ & 20122 & 366 \\
\hline кручина & 2 & 8390 & $0.02 \%$ & $-0.105 \%$ & $0.13 \%$ & 20122 & 26 \\
\hline кручиниться & 0 & 8390 & $0.00 \%$ & $-0.065 \%$ & $0.06 \%$ & 20122 & 13 \\
\hline кручинный & 0 & 8390 & $0.00 \%$ & $-0.005 \%$ & $0.00 \%$ & 20122 & 1 \\
\hline кручинушка & 0 & 8390 & $0.00 \%$ & $-0.010 \%$ & $0.01 \%$ & 20122 & 2 \\
\hline крушить & 22 & 8390 & $0.26 \%$ & $-0.190 \%$ & $0.45 \%$ & 20122 & 91 \\
\hline кукситься & 1 & 8390 & $0.01 \%$ & $-0.013 \%$ & $0.02 \%$ & 20122 & 5 \\
\hline меланхолик & 8 & 8390 & $0.10 \%$ & $-0.044 \%$ & $0.14 \%$ & 20122 & 28 \\
\hline меланхолический & 13 & 8390 & $0.15 \%$ & $-0.615 \%$ & $0.77 \%$ & 20122 & 155 \\
\hline меланхоличка & 0 & 8390 & $0.00 \%$ & $0.000 \%$ & $0.00 \%$ & 20122 & 0 \\
\hline меланхоличность & 1 & 8390 & $0.01 \%$ & $-0.003 \%$ & $0.01 \%$ & 20122 & 3 \\
\hline меланхолия & 39 & 8390 & $0.46 \%$ & $-0.151 \%$ & $0.62 \%$ & 20122 & 124 \\
\hline мрачнеть & 17 & 8390 & $0.20 \%$ & $-0.031 \%$ & $0.23 \%$ & 20122 & 47 \\
\hline мрачность & 21 & 8390 & $0.25 \%$ & $-0.117 \%$ & $0.37 \%$ & 20122 & 74 \\
\hline мрачный & 285 & 8390 & $3.40 \%$ & $-2.835 \%$ & $6.23 \%$ & 20122 & 1254 \\
\hline муторный & 11 & 8390 & $0.13 \%$ & $0.012 \%$ & $0.12 \%$ & 20122 & 24 \\
\hline мымра & 1 & 8390 & $0.01 \%$ & $-0.013 \%$ & $0.02 \%$ & 20122 & 5 \\
\hline надоедать & 55 & 8390 & $0.66 \%$ & $-0.512 \%$ & $1.17 \%$ & 20122 & 235 \\
\hline надоедливость & 0 & 8390 & $0.00 \%$ & $-0.025 \%$ & $0.02 \%$ & 20122 & 5 \\
\hline надоедливый & 12 & 8390 & $0.14 \%$ & $-0.319 \%$ & $0.46 \%$ & 20122 & 93 \\
\hline надоесть & 232 & 8390 & $2.77 \%$ & $-1.022 \%$ & $3.79 \%$ & 20122 & 762 \\
\hline надсадный & 9 & 8390 & $0.11 \%$ & $0.018 \%$ & $0.09 \%$ & 20122 & 18 \\
\hline назойливость & 7 & 8390 & $0.08 \%$ & $-0.160 \%$ & $0.24 \%$ & 20122 & 49 \\
\hline назойливый & 60 & 8390 & $0.72 \%$ & $-0.647 \%$ & $1.36 \%$ & 20122 & 274 \\
\hline назола & 0 & 8390 & $0.00 \%$ & $0.000 \%$ & $0.00 \%$ & 20122 & 0 \\
\hline наскучаться & 0 & 8390 & $0.00 \%$ & $-0.005 \%$ & $0.00 \%$ & 20122 & 1 \\
\hline наскучить & 31 & 8390 & $0.37 \%$ & $-0.381 \%$ & $0.75 \%$ & 20122 & 151 \\
\hline натосковаться & 0 & 8390 & $0.00 \%$ & $0.000 \%$ & $0.00 \%$ & 20122 & 0 \\
\hline нахмуриться & 23 & 8390 & $0.27 \%$ & $-0.273 \%$ & $0.55 \%$ & 20122 & 110 \\
\hline невеселый & 69 & 8390 & $0.82 \%$ & $-0.594 \%$ & $1.42 \%$ & 20122 & 285 \\
\hline неотвязный & 11 & 8390 & $0.13 \%$ & $-0.122 \%$ & $0.25 \%$ & 20122 & 51 \\
\hline неотвязчивый & 2 & 8390 & $0.02 \%$ & $-0.100 \%$ & $0.12 \%$ & 20122 & 25 \\
\hline
\end{tabular}




\begin{tabular}{|c|c|c|c|c|c|c|c|}
\hline нерадостный & 10 & 8390 & $0.12 \%$ & $-0.129 \%$ & $0.25 \%$ & 20122 & 50 \\
\hline несносный & 32 & 8390 & $0.38 \%$ & $-0.667 \%$ & $1.05 \%$ & 20122 & 211 \\
\hline ностальгия & 99 & 8390 & $1.18 \%$ & $0.126 \%$ & $1.05 \%$ & 20122 & 212 \\
\hline нудный & 48 & 8390 & $0.57 \%$ & $-0.317 \%$ & $0.89 \%$ & 20122 & 179 \\
\hline омрачаться & 4 & 8390 & $0.05 \%$ & $-0.151 \%$ & $0.20 \%$ & 20122 & 40 \\
\hline опечаленный & 0 & 8390 & $0.00 \%$ & $0.000 \%$ & $0.00 \%$ & 20122 & 0 \\
\hline опечаливать & 1 & 8390 & $0.01 \%$ & $-0.003 \%$ & $0.01 \%$ & 20122 & 3 \\
\hline опечалить & 14 & 8390 & $0.17 \%$ & $-0.425 \%$ & $0.59 \%$ & 20122 & 119 \\
\hline опечалиться & 7 & 8390 & $0.08 \%$ & $-0.066 \%$ & $0.15 \%$ & 20122 & 30 \\
\hline опостынуть & 0 & 8390 & $0.00 \%$ & $-0.015 \%$ & $0.01 \%$ & 20122 & 3 \\
\hline опостыть & 0 & 8390 & $0.00 \%$ & $-0.015 \%$ & $0.01 \%$ & 20122 & 3 \\
\hline осточертеть & 14 & 8390 & $0.17 \%$ & $-0.146 \%$ & $0.31 \%$ & 20122 & 63 \\
\hline отчаиваться & 54 & 8390 & $0.64 \%$ & $-0.062 \%$ & $0.71 \%$ & 20122 & 142 \\
\hline отчаяние & 256 & 8390 & $3.05 \%$ & $-1.894 \%$ & $4.94 \%$ & 20122 & 995 \\
\hline отчаянный & 234 & 8390 & $2.79 \%$ & $-2.176 \%$ & $4.96 \%$ & 20122 & 999 \\
\hline отчаяться & 70 & 8390 & $0.83 \%$ & $-0.284 \%$ & $1.12 \%$ & 20122 & 225 \\
\hline пессимизм & 47 & 8390 & $0.56 \%$ & $-0.498 \%$ & $1.06 \%$ & 20122 & 213 \\
\hline пессимист & 24 & 8390 & $0.29 \%$ & $-0.430 \%$ & $0.72 \%$ & 20122 & 144 \\
\hline пессимистический & 38 & 8390 & $0.45 \%$ & $-0.367 \%$ & $0.82 \%$ & 20122 & 165 \\
\hline пессимистичность & 0 & 8390 & $0.00 \%$ & $0.000 \%$ & $0.00 \%$ & 20122 & 0 \\
\hline пессимистка & 4 & 8390 & $0.05 \%$ & $0.033 \%$ & $0.01 \%$ & 20122 & 3 \\
\hline печалить & 78 & 8390 & $0.93 \%$ & $-0.715 \%$ & $1.64 \%$ & 20122 & 331 \\
\hline печалиться & 29 & 8390 & $0.35 \%$ & $-0.271 \%$ & $0.62 \%$ & 20122 & 124 \\
\hline печаловаться & 0 & 8390 & $0.00 \%$ & $-0.045 \%$ & $0.04 \%$ & 20122 & 9 \\
\hline печаль & 141 & 8390 & $1.68 \%$ & $-1.291 \%$ & $2.97 \%$ & 20122 & 598 \\
\hline печальник & 1 & 8390 & $0.01 \%$ & $-0.063 \%$ & $0.07 \%$ & 20122 & 15 \\
\hline печальница & 0 & 8390 & $0.00 \%$ & $-0.010 \%$ & $0.01 \%$ & 20122 & 2 \\
\hline печальный & 431 & 8390 & $5.14 \%$ & $-3.083 \%$ & $8.22 \%$ & 20122 & 1654 \\
\hline погрустить & 4 & 8390 & $0.05 \%$ & $-0.047 \%$ & $0.09 \%$ & 20122 & 19 \\
\hline подавленность & 21 & 8390 & $0.25 \%$ & $-0.068 \%$ & $0.32 \%$ & 20122 & 64 \\
\hline подосадовать & 4 & 8390 & $0.05 \%$ & $-0.012 \%$ & $0.06 \%$ & 20122 & 12 \\
\hline покручиниться & 0 & 8390 & $0.00 \%$ & $-0.005 \%$ & $0.00 \%$ & 20122 & 1 \\
\hline помрачиться & 1 & 8390 & $0.01 \%$ & $-0.033 \%$ & $0.04 \%$ & 20122 & 9 \\
\hline
\end{tabular}


Danko Šipka

\begin{tabular}{|c|c|c|c|c|c|c|c|}
\hline помрачнеть & 9 & 8390 & $0.11 \%$ & $-0.067 \%$ & $0.17 \%$ & 20122 & 35 \\
\hline понуриться & 0 & 8390 & $0.00 \%$ & $-0.050 \%$ & $0.05 \%$ & 20122 & 10 \\
\hline понурость & 0 & 8390 & $0.00 \%$ & $0.000 \%$ & $0.00 \%$ & 20122 & 0 \\
\hline понурый & 18 & 8390 & $0.21 \%$ & $-0.233 \%$ & $0.45 \%$ & 20122 & 90 \\
\hline посетовать & 61 & 8390 & $0.73 \%$ & $-0.212 \%$ & $0.94 \%$ & 20122 & 189 \\
\hline поскучать & 5 & 8390 & $0.06 \%$ & $0.000 \%$ & $0.06 \%$ & 20122 & 12 \\
\hline поскучнеть & 5 & 8390 & $0.06 \%$ & $-0.015 \%$ & $0.07 \%$ & 20122 & 15 \\
\hline потомить & 2 & 8390 & $0.02 \%$ & $0.004 \%$ & $0.02 \%$ & 20122 & 4 \\
\hline потомиться & 0 & 8390 & $0.00 \%$ & $-0.010 \%$ & $0.01 \%$ & 20122 & 2 \\
\hline потосковать & 0 & 8390 & $0.00 \%$ & $-0.015 \%$ & $0.01 \%$ & 20122 & 3 \\
\hline потужить & 1 & 8390 & $0.01 \%$ & $-0.033 \%$ & $0.04 \%$ & 20122 & 9 \\
\hline прискучивать & 0 & 8390 & $0.00 \%$ & $-0.010 \%$ & $0.01 \%$ & 20122 & 2 \\
\hline приунывать & 0 & 8390 & $0.00 \%$ & $0.000 \%$ & $0.00 \%$ & 20122 & 0 \\
\hline приуныть & 10 & 8390 & $0.12 \%$ & $-0.129 \%$ & $0.25 \%$ & 20122 & 50 \\
\hline протомить & 0 & 8390 & $0.00 \%$ & $0.000 \%$ & $0.00 \%$ & 20122 & 0 \\
\hline раздосадовать & 14 & 8390 & $0.17 \%$ & $-0.295 \%$ & $0.46 \%$ & 20122 & 93 \\
\hline раздосадоваться & 0 & 8390 & $0.00 \%$ & $-0.010 \%$ & $0.01 \%$ & 20122 & 2 \\
\hline раскваситься & 0 & 8390 & $0.00 \%$ & $-0.015 \%$ & $0.01 \%$ & 20122 & 3 \\
\hline расквашиваться & 0 & 8390 & $0.00 \%$ & $0.000 \%$ & $0.00 \%$ & 20122 & 0 \\
\hline растосковаться & 0 & 8390 & $0.00 \%$ & $0.000 \%$ & $0.00 \%$ & 20122 & 0 \\
\hline растужиться & 0 & 8390 & $0.00 \%$ & $0.000 \%$ & $0.00 \%$ & 20122 & 0 \\
\hline сгрустнуться & 0 & 8390 & $0.00 \%$ & $-0.010 \%$ & $0.01 \%$ & 20122 & 2 \\
\hline сетовать & 136 & 8390 & $1.62 \%$ & $-0.208 \%$ & $1.83 \%$ & 20122 & 368 \\
\hline скука & 142 & 8390 & $1.69 \%$ & $-1.225 \%$ & $2.92 \%$ & 20122 & 587 \\
\hline скукситься & 0 & 8390 & $0.00 \%$ & $-0.020 \%$ & $0.02 \%$ & 20122 & 4 \\
\hline скучать & 182 & 8390 & $2.17 \%$ & $-0.390 \%$ & $2.56 \%$ & 20122 & 515 \\
\hline скучища & 9 & 8390 & $0.11 \%$ & $0.033 \%$ & $0.07 \%$ & 20122 & 15 \\
\hline скучливый & 0 & 8390 & $0.00 \%$ & $-0.010 \%$ & $0.01 \%$ & 20122 & 2 \\
\hline скучнеть & 2 & 8390 & $0.02 \%$ & $-0.036 \%$ & $0.06 \%$ & 20122 & 12 \\
\hline скучный & 379 & 8390 & $4.52 \%$ & $-1.262 \%$ & $5.78 \%$ & 20122 & 1163 \\
\hline смурой & 0 & 8390 & $0.00 \%$ & $0.000 \%$ & $0.00 \%$ & 20122 & 0 \\
\hline смурость & 0 & 8390 & $0.00 \%$ & $0.000 \%$ & $0.00 \%$ & 20122 & 0 \\
\hline сожаление & 887 & 8390 & $10.57 \%$ & $-3.760 \%$ & $14.33 \%$ & 20122 & 2884 \\
\hline
\end{tabular}




\begin{tabular}{|c|c|c|c|c|c|c|c|}
\hline сожалеть & 76 & 8390 & $0.91 \%$ & $-1.306 \%$ & $2.21 \%$ & 20122 & 445 \\
\hline сокрушаться & 51 & 8390 & $0.61 \%$ & $-0.451 \%$ & $1.06 \%$ & 20122 & 213 \\
\hline сокрушительность & 0 & 8390 & $0.00 \%$ & $0.000 \%$ & $0.00 \%$ & 20122 & 0 \\
\hline соскучиться & 71 & 8390 & $0.85 \%$ & $-0.018 \%$ & $0.86 \%$ & 20122 & 174 \\
\hline сплин & 8 & 8390 & $0.10 \%$ & $-0.089 \%$ & $0.18 \%$ & 20122 & 37 \\
\hline стосковаться & 11 & 8390 & $0.13 \%$ & $-0.008 \%$ & $0.14 \%$ & 20122 & 28 \\
\hline сушь & 46 & 8390 & $0.55 \%$ & $-0.550 \%$ & $1.10 \%$ & 20122 & 221 \\
\hline томный & 52 & 8390 & $0.62 \%$ & $-0.339 \%$ & $0.96 \%$ & 20122 & 193 \\
\hline тоска & 265 & 8390 & $3.16 \%$ & $-1.359 \%$ & $4.52 \%$ & 20122 & 909 \\
\hline тоскливость & 0 & 8390 & $0.00 \%$ & $-0.015 \%$ & $0.01 \%$ & 20122 & 3 \\
\hline тоскливый & 88 & 8390 & $1.05 \%$ & $-0.517 \%$ & $1.57 \%$ & 20122 & 315 \\
\hline тосковать & 111 & 8390 & $1.32 \%$ & $-0.734 \%$ & $2.06 \%$ & 20122 & 414 \\
\hline угоняться & 1 & 8390 & $0.01 \%$ & $-0.053 \%$ & $0.06 \%$ & 20122 & 13 \\
\hline унывать & 45 & 8390 & $0.54 \%$ & $-0.294 \%$ & $0.83 \%$ & 20122 & 167 \\
\hline унывный & 1 & 8390 & $0.01 \%$ & $-0.018 \%$ & $0.03 \%$ & 20122 & 6 \\
\hline унылость & 8 & 8390 & $0.10 \%$ & $-0.029 \%$ & $0.12 \%$ & 20122 & 25 \\
\hline унылый & 130 & 8390 & $1.55 \%$ & $-1.278 \%$ & $2.83 \%$ & 20122 & 569 \\
\hline уныние & 72 & 8390 & $0.86 \%$ & $-1.025 \%$ & $1.88 \%$ & 20122 & 379 \\
\hline утепление & 17 & 8390 & $0.20 \%$ & $0.118 \%$ & $0.08 \%$ & 20122 & 17 \\
\hline утомительный & 73 & 8390 & $0.87 \%$ & $-0.884 \%$ & $1.75 \%$ & 20122 & 353 \\
\hline утомить & 87 & 8390 & $1.04 \%$ & $-1.150 \%$ & $2.19 \%$ & 20122 & 440 \\
\hline утомлять & 50 & 8390 & $0.60 \%$ & $-0.517 \%$ & $1.11 \%$ & 20122 & 224 \\
\hline хандра & 18 & 8390 & $0.21 \%$ & $-0.138 \%$ & $0.35 \%$ & 20122 & 71 \\
\hline хандрить & 8 & 8390 & $0.10 \%$ & $-0.069 \%$ & $0.16 \%$ & 20122 & 33 \\
\hline хмуриться & 22 & 8390 & $0.26 \%$ & $-0.294 \%$ & $0.56 \%$ & 20122 & 112 \\
\hline хмуро & 26 & 8390 & $0.31 \%$ & $-0.177 \%$ & $0.49 \%$ & 20122 & 98 \\
\hline хмурый & 83 & 8390 & $0.99 \%$ & $-0.497 \%$ & $1.49 \%$ & 20122 & 299 \\
\hline хмурь & 0 & 8390 & $0.00 \%$ & $-0.005 \%$ & $0.00 \%$ & 20122 & 1 \\
\hline элегичность & 1 & 8390 & $0.01 \%$ & $-0.013 \%$ & $0.02 \%$ & 20122 & 5 \\
\hline элегичный & 0 & 8390 & $0.00 \%$ & $-0.025 \%$ & $0.02 \%$ & 20122 & 5 \\
\hline
\end{tabular}

